PressAcademia Procedia

Global Business Research Congress, June 4-5, 2020

\title{
CONCEPTUALIZATION OF SOCIAL MEDIA BRAND EQUITY
}

\author{
DOI: 10.17261/Pressacademia.2020.1245 \\ PAP- V.11-2020(17)-p.84-87
}

Dina Sadyk

KIMEP University, Management and Marketing Department, Almaty, Kazakhstan Dina.Sadyk@kimep.kz, ORCID: 0000-0003-3622-1609

To cite this document

Sadyk D. (2020). Conceptualization of social media brand equity. PressAcademia Procedia (PAP), V.11, p.84-87

Permanent link to this document: http://doi.org/10.17261/Pressacademia.2020.1245

Copyright: Published by PressAcademia and limited licensed re-use rights only.

\section{ABSTRACT}

Purpose - While brand equity is widely recognized as one of the most important areas of strategic marketing, it is a rather new and complex research topic in social media context. Hitherto, there is no acknowledged concept of social media brand equity or unified approach of its estimation. The purpose of this study is to suggest a conceptualization of social media brand equity (SMBE) through analysis of the main challenges and drivers of extant explorations in the related areas.

Methodology - Out of 225 revised scholarly papers about social media and brand valuation, there are scant number of studies that propose a model for SMBE measurement. Based on the literature review a theoretical proposal is elaborated to understand the concept of SMBE. Findings - Results show that consumer-related factors have a significant impact on SMBE building due to the active involvement of users in the value co-creation process, which is facilitated by numerous social media inherent features. Therefore, customer-based brand equity (CBBE) may be the initial platform for elaboration of the SMBE concept and subsequent development of its measurement scale.

Conclusion - Conceptualization of SMBE contributes to the development of the reasonable assessment model available for scholars and practitioners for the brand valuation of social media firms.

Keywords: Social media brand equity, customer-based brand equity, social media, brand valuation. JEL Codes: M30, M31, M39

\section{INTRODUCTION}

Social media are worldwide virtual publishing houses based on Web platforms and enhanced with online tools and technologies, which allow people to create and release their content as well as to use the content of other people regardless of their locations, professions, and social statuses. The intrinsic features, namely ubiquitous availability $24 / 7$, impressive speed of information spreading, easiness and convenience of usage, make social media a powerful force of global changes in almost all areas of human life including social, political, environmental and technological aspects.

Social media grew to almost 3 billion users in 2019 with a CAGR of $8.4 \%$ since 2015 (Clement, 2020). The big scale and dynamic evolvement of social media firms entail a necessity of their brands' valuation. Interbrand has been appraising a brand value for Facebook since 2012, Spotify since 2018, and LinkedIn since 2019 with the application of their patented measurement model (Interbrand, n.d.). Yet, there is no brand valuation method for social media, which is widely accepted and available for academic and business practices.

One of the specific challenges in the development of brand valuation technique for social media is that a monetary estimation of advantages for users is impeded by the non-paid nature of social media' services, whereas the economical approach to measure a value of product or service is based on a consumer surplus or a difference between the actual price and the price that customer would be willing to pay for it (Corrigan, Alhabash, Rousu, \& Cash, 2018).

The extended view of brand valuation of online companies shows that from the financial perspective, the assessment of web-based companies is complicated by the high speed of their growth and related ambiguity in variable expenses, opportunistic financial resources (Schosser \& Ströbele, 2019) along with impracticality of traditional forecasts about exchange listing and income (Klobucnik \& Sievers, 2013).

From the marketing perspective, no brand equity concept or measurement scale is recognized for social media considering their idiosyncrasy. The purpose of this study is to conceptualize social media brand equity (SMBE) through investigation of the main challenges and drivers of ongoing explorations in the areas of social media, brand equity, and brand valuation. The SMBE concept may considerably contribute to the brand equity theory in the contemporary online setting. 


\section{LITERATURE REVIEW}

A brand is a foundation for building a sustainable value of a firm and its successful future (Aaker, 2014). Hence, it is widely recognized as a strategic firm's intangible asset (Arora \& Chaudhary, 2016). It has a direct effect on the firm's financial performance, the stronger brand with successful branding has a higher value, which consequently contributes to the higher firm's value and its stock prices (Hsu, Wang, \& Chen, 2013). For example, Ozyesil (2019) established a $2.21 \%$ increase in a stock price due to a $1 \%$ increase in brand value in the Turkish retail and sport sectors.

The first case of the inclusion of 60 brands by the worth of $\$ 1.2$ billion to the balance sheet of Ranks Hovis McDougall was reported more than 30 years ago (Aaker, 1991). But even so, the brand value is an obligatory line in the financial reporting system in only a few developed countries such as Great Britain, New Zealand, Australia, and the United States, where the most of strong and successful global brands were created (Terzic \& Dalic, 2019). A challenge is that brand valuation requires a consideration of associated marketing and finance factors, which directly impact on the overall firm value (Kumar, Sujit, \& Abdul, 2019). There are numerous measurement techniques proposed for brand valuation, however, these different methods bring different and contestable results (Avery, 2018) that motivate scholars for further investigations in the field.

The brand value is a monetary estimation based on consumer evaluation of the brand worth or brand equity, which is formed by various stakeholders including suppliers and distributors, governments and NGOs, media and public opinion, competitors, and employees (Jones, 2005). Overall, the brand equity is viewed as a favorable marketing effect of the individual brand name on a certain product or service (Davcik et al., 2015). Existing classical definitions of brand equity emphasize a positive or negative value provided by the brand to the product (Farquhar, 1989; Aaker, 1991) meaning that the brand impacts consumer choice between branded and non-branded products with similar attributes (Yoo, Donthu, \& Lee, 2000).

Brand equity is acknowledged as the major strategic concept with the two main paradigms applied in contemporary marketing theory and practice (Davcik, Silva, \& Hair, 2015). The first is the finance-based brand equity (FBBE) measured as a financial value of the brand indicating its achievements. The second is the customer-based brand equity (CBBE) yielded through the interrelationship between customer and brand.

The CBBE concept is grounded on cognitive psychology to explain a brand knowledge, one of the key CBBE facets, formed within the structure of human memory and measured by two dimensions such as brand awareness and brand associations (Aaker, 1991; Keller, 1993). Aaker (1991) defines that the wide awareness of the brand name, strong consumers' associations with the brand, high brand loyalty, and favorable perceived quality of product or service lead to increasing CBBE, and consequently rising the brand value for customers and the firm.

An academic interest in the area of online brands' equities measurement emerged after the dotcom crisis in 2001, when newborn online companies including Amazon.com, Yahoo!, Google, eBay, Facebook not only survived but even overgrew traditional offline companies in terms of brand equity (Rios \& Riquelme, 2010). The alternative evaluation systems with unique Internet dimensions are proposed, e.g. Online Retail/Service or ORS for estimation of retail brand equity of Internet firms (Christodoulides, Chernatoni, F urrer, Shiu, \& Abimbola, 2006). The special terms like e-brand equity (Le, Tran L.T.T., Pham, \& Tran D.T.D., 2018), website brand equity (Liyin, 2009), online brand equity (Rana, Bhat, \& Rani, 2015), and Consumer-Based E-business Brand Equity (Ma, 2016) exemplify a customized approach to brand equity in online context to point out its virtual character.

Regarding social media, one of the actual research areas is a noticeable impact of social media and social media marketing (SMM) on brand equity assessment. For instance, social media are effectively used in brand equity estimation through the data retrieving and analysis with virtual techniques like NodeXL, Rapid Miner tool, and sentiment analysis, which are easier and faster tools than traditional methods of offline or online survey with questionnaires (Noguera \& Tsunoda, 2018). Also, social media factors are found as more indicative and faster brand equity metrics like Web blogs and consumers' rating volume than standard measures of online consumer behavior such as Web traffic and Internet search (Luo, Zhang, \& Duan, 2013).

Concerning the brand equity creation process, the important role of SMM factors is commonly recognized (Jayasuriya \& Azam, 2017). There are 16 various SMM antecedents of brand equity found through the search. The most common are the engagement (Chanal \& Rani, 2017) and eWOM (Sijoria, Mukherjee, \& Datta, 2018) that empirically verified. Among other confirmed antecedents are interaction, entertainment, trendiness, customization (Godey et al., 2016), experience (Koay, Ong, Khoo, Yeoh, 2020), etc. The reviewed papers are based on a single social media platforms, mostly on Facebook and Twitter. However, consumers apply a sharing behavior throughout various social media (Ham, Lee, Hayes, \& Bae, 2019), they have multiple-platforms' usage experience to communicate to different audiences adjusting content to their distinct needs, preferences, and norms as well as to particular features of varying types of social media (Zhao, Lampe, \& Ellison, 2016). Thus, empirical investigations may be further enhanced with multi-platform samples do not overlook the real consumer behavior and reveal the universal social media factors of SMBE.

One of the actual research questions is about SMM impact on the brand equity of social media themselves (Kavisekera \& Abeysekera, 2016). However, few papers suggest SMBE scales, which have alternative dimensions got from single-platform data analysis. The current sporadic approach to SMBE investigations can be systemized through elaboration of theoretically justified SMBE concept.

Based on literature, value co-creation is a reasonable theory to be adopted as a background for SMBE conceptualization. The easy and fast online communications' flow between the firm and the customer, facilitated by social media, define a social aspect of brand equity building, where the consumer is not anymore a passive user but an active contributor or co-creator of the brand equity, and so brand is considered as a social process (Iglesias, Ind, \& Alfaro, 2013), whereas social media are seeing as the integrative resource contributor to the firm value on par with customer and firm (Singaraju, Nguyen, Niininen, \& Sullivan-Mort, 2016). 


\section{METHODOLOGY}

This study encompasses 225 academic papers and other 103 sources of information including Ph.D. theses, books, white papers, as well as articles from scientific conferences, universities', business, and online journals. The review covers researches of brand valuation for social media companies and other diverse businesses, where social media are actively adopted for their brand's building and promotion. The papers investigate casual relationships between social media antecedents and brand equity through theoretical and empirical analyses. The literature search was used to find and analyze the challenges and drivers of SMBE comprising different CBBE models for social media for the past ten years.

\section{FINDINGS}

There is a scarce number of papers that have addressed the creation of the SMBE model to measure the equity of social media brands. The study's results show that consumer-related factors have a significant impact on brand equity creation of SMBE due to the active involvement of customers in the value co-creation process, which is facilitated by numerous social media characteristics. Therefore, CBBE may be the platform to form the SMBE model.

Whilst, the classical CBBE scale has been developed and verified by numerous studies in offline settings, as yet it has not been sufficiently retested in the social media environment by empirical investigations. Even more, no universal social media-based factors of CBBE are acknowledged. It is a big challenge as universal social media measures can be used as a meaningful indicator of brand equity of offline a nd online firms because of their reliable prediction capability of the future company's sales (Luo et al., 2013). As soon as the general social media predictors are defined, the fundamental income approach to estimate a firm's value may be adapted for social media with insufficient transactional data and comparable market information (Loughnane, Plastino, \& Altman, 2015).

Considering multi-platforms usage experience crosswise social media networks, SMBE model development can be tested as a general measurement scale for social media.

SMBE may be conceptualized as a distinct type of online CBBE that is co-created with consumers due to specific attributes of social media, which generate the consumer's behavioral antecedents such as engagement, eWOM, UGC, interaction, experience, and other social mediaspecific sources of brand equity. The traditional CBBE scale including brand awareness, perceived quality, brand loyalty, and brand associations should be re-tested in social media context as a basic construct of the SMBE model, enhanced with engagement and eWOM as social media sources of brand equity.

\section{CONCLUSION}

There are various social media-related CBBE antecedents proposed by scholars for the last decade, however, no social media-based brand equity (SMBE) concept or unified measurement scale is recognized to estimate brand equity of social media brands. The survey defined the main elements of the SMBE model for empirical analysis, which is the conventional CBBE scale augmented with social media antecedents based on value co-creation theory. The development of the SMBE concept contributes to filling the gap in the social media research field by a further systematic construction of a reasonable, credible, and parsimonious SMBE scale for measurement of the brand equity of social media firms. The actuality and importance of this academic topic is conditioned by the ongoing rise of social media firms in their quantity and scale.

\section{REFERENCES}

Aaker, D. A. (1991). Managing Brand Equity. Free Press, NY.

Aaker, D. A. (2014). Aaker on branding: 20 principles that drive success. New York, by Morgan James Publishing.

Arora S., Chaudhary, N. (2016). Impact of Brand Value on Financial Performance of Banks: An Empirical Study on Indian Banks. Universal Journal of Industrial and Business Management, 4(3): 88-96.

Avery, J. (2018). The Art and Science of Brand Valuation. Harvard Business School Technical Note 518-086, February. (Revised October 2019.)

Chahal, H., Rani, A. (2017). How trust moderates social media engagement and brand equity. Journal of Research in Interactive Marketing, 11(3): 312-335.

Christodoulides, G., De Chernatony, L., Furrer, O., Shiu, E., Abimbola, T. (2006). Conceptualizing and Measuring the Equity of Online Brands. Journal of Marketing Management, 22(7-8): 799-825.

Clement, J. (2020, April 1). Number of global social network users 2010-2023. Retrieved from https://www.statista.com/statistics/278414/number-of-worldwide-social-network-users/

Corrigan, J. R., Alhabash, S., Rousu, M., Cash, S. B. (2018). How Much Is Social Media Worth? Estimating the Value of Facebook by Paying Users to Stop Using It. PLOS ONE 13(12): 1-11.

Davcik, N. S., da Silva, R. V., Hair, J. F. (2015). Towards a Unified Theory of Brand Equity: Conceptualizations, Taxonomy and Avenues for Future Research. Journal of Product \& Brand Management, 24(1): 3-17.

Farquhar, P. H. (1989). Managing Brand Equity. Marketing Research, September: 24-33. 
Godey, B., Manthiou, A., Pederzoli, D., Rokka, J., Aiello, G., Donvito, R., Singh, R. (2016). Social media marketing efforts of luxury brands: Influence on brand equity and consumer behavior. Journal of Business Research, 69: 5833-5841.

Ham, C-D, Lee, J., Hayes, J.L., Bae, Y.H. (2019). Exploring Sharing Behaviors across Social Media Platforms. International Journal of Market Research, 61(2): 157-177.

Hsu, F. J., Wang, T. Y., Chen, M. Y. (2013). The Impact of Brand Value on Financial Performance. Advances in Management \& Applied Economics, 3(6): 129-141.

Iglesias, O., Ind, N., Alfaro, M. (2013). The organic view of the brand: A brand value co-creation model. Journal of Brand Management, 20(8): 670-688.

Interbrand. (n.d.). Best Global Brands 2019 Rankings. Retrieved from https://www.interbrand.com/best-brands/best-globalbrands/2019/ranking/

Jayasuriya, N.A., Azam, S.M.F. (2017). The Impact of Social Media Marketing on Brand Equity: A Study of Fashion-Wear Retail in Sri Lanka. International Review of Management and Marketing, 7(5): 178-183.

Jing, MA (2016). The Influence of Consumer-Based E-business Brand Equity on Websites. International Conference on Economics and Business Management (EBM 2016).

Jones, R. (2005). Finding sources of brand value: Developing a stakeholder model of brand equity. Journal of Brand Management, 13: 10-32 Kavisekera, S., Abeysekera, N. (2016). Effect of social media marketing on brand equity of online companies. Management \& Marketing, 14(2): 201-216

Keller, K. L. (1993). Conceptualizing, Measuring, and Managing Customer-Based Brand Equity. Journal of Marketing, 57(1): 1-22.

Klobucnik, J., Sievers, S. (2013). Valuing High Technology Growth Firms. Journal of Business Economics, 83: 947-984.

Koay, K. Y., Ong, D.L.T., Khoo, K. L, Yeoh, H.J. (2020). Perceived Social Media Marketing Activities and Consumer-Based Brand Equity: Testing a Moderated Mediation Model. Asia Pacific Journal of Marketing and Logistics, Vol. ahead-of-print No. ahead-of-print.

Kumar, B. R., Sujit, K.S., Abdul, W. K. (2019). Brand Valuation - Examining the Role of Marketing on Firm Financial Performance. Measuring Business Excellence, 24(1): 90-113.

Le, L.T., Tran, L.T.T, Pham, L.M.T., Tran, D.T.D. (2018). A Revised Model of E-Brand Equity and Its Application to High Technology Products. The Journal of High Technology Management Research 29(2): 151-60.

Liyin, J. (2009). Dimensions and determinants of website brand equity: From the perspective of website contents. Front. Business Research China, 3(4): 514-542.

Loughnane, J. G., Plastino, D., Altman, E. (2015). Valuation of Social Media Assets. AMI Journal, December Issue: 36-39.

Luo, X., Zhang, J., Duan, W. (2013). Social Media and Firm Equity Value. Information Systems Research, 24(1): 146-163.

Nogueira, E., Tsunoda, D.F. (2018). A Proposed Model for Consumer-Based Brand Equity Analysis on Social Media Using Data Mining and Social Network Analysis. Journal of Relationship Marketing, 17(2): 95-117.

Ozyesil, M. (2019). Relationship Between Brand Value, Firm Size and Stock Price Performance: $2^{\text {nd }}$ Generation Panel Data Analysis on Turkish Retail Sector and Sport Clubs. International Journal of Economics and Financial Issues, 9(5): 38-43.

Rios, R. E., Riquelme, H. E. (2010). Sources of brand equity for online companies. Journal of Research in Interactive Marketing, 4(3): 214-240.

Schosser, J., Ströbele, H. (2019). What Is the Value of Facebook? Evidence from the Schwartz/Moon Model. The Journal of Risk Finance, 20(3): 267-290.

Sijoria, C., Mukherjee, S., Datta, B. (2018). Impact of the Antecedents of EWOM on CBBE. Marketing Intelligence \& Planning, 36(5): 528-542.

Singaraju, S. P., Nguyen, Q. A., Niininen, O., Sullivan-Mort, G. (2016). Social media and value co-creation in multi-stakeholder systems: A resource integration approach. Industrial Marketing Management, 54: 44-55.

Terzić, S., Đalić, I. (2019). Analysis of the Brand Valuation Based on the Assessment by Interbrand, Brand Finance and Milward Brown Optimor. Acta Economica, 17(30): 59-82.

Yoo, B., Donthu, N., Lee, S. (2000). An examination of selected marketing mix elements and brand equity. Journal of the Academy of Marketing Science, 28(2): 195-211.

Zhao, X., Lampe, C., Ellison, N.B. (2106). The Social Media Ecology: User Perceptions, Strategies and Challenges. In Proceedings of the 2016 $\mathrm{CHI}$ Conference on Human Factors in Computing Systems, 89-100. 